\title{
Frontières
}

\section{Filmographie indicative}

Volume 15, numéro 2, printemps 2003

URI : https://id.erudit.org/iderudit/1073833ar

DOI : https://doi.org/10.7202/1073833ar

Aller au sommaire du numéro

Éditeur(s)

Université du Québec à Montréal

ISSN

1180-3479 (imprimé)

1916-0976 (numérique)

Découvrir la revue

Citer ce document

(2003). Filmographie indicative. Frontières, 15(2), 89-89.

https://doi.org/10.7202/1073833ar

Ce document est protégé par la loi sur le droit d'auteur. L'utilisation des services d'Érudit (y compris la reproduction) est assujettie à sa politique d'utilisation que vous pouvez consulter en ligne.

https://apropos.erudit.org/fr/usagers/politique-dutilisation/
Cet article est diffusé et préservé par Érudit.

Érudit est un consortium interuniversitaire sans but lucratif composé de l’Université de Montréal, l'Université Laval et l'Université du Québec à Montréal. Il a pour mission la promotion et la valorisation de la recherche. https://www.erudit.org/fr/ 


\section{FILMOGRAPHIE INDICATIVE}

\section{LES GISANTS ET LES MORTS}

France, 2000, BETACAM,

couleurs, 25 min.

Réalisation et scénario:

Alain BERGALA

Productrice : Muriel SORBO

Production: Musée du Louvre /

Musée d'Orsay/Centre Georges-

Pompidou/Réunion des Musées

Nationaux / La Cinquième /

Les Films du Tambour de Soie,

Les Scénarios de l'art

Distribution: France Télévision

Les gisants, ce sont des sculptures funéraires représentant un personnage couché sur son lit de mort. Un film de 25 minutes d'Alain Bergala sur « les gisants et les morts à travers leurs représentations dans la peinture, la sculpture et la photographie " (Programme du 21 $1^{\mathrm{e}}$ Festival International du film sur l'art, Montréal, 13-23 mars 2003, p. 104). La représentation de la mort, sa «mise en scène », nous est présentée au fil des époques, de la Pietà de MichelAnge aux tranchées des guerres mondiales du XXe siècle et à la Shoah.

\section{PHOTOGRAPHE DE}

GUERRE / JAMES NACHTWEY

(WAR PHOTOGRAPHER)

Christian FREI, Suisse, 2001

96 min., v.o. anglaise

Documentaire : Christiane

Amanpour, Hans-Herman Klare, James Nachtwey

Un reportage de grande qualité qui nous permet d'accompagner sur les lieux des conflits armés, entre autre au Moyen Orient, James Nachtwey ce photographe américain, diplômé de l'Université Darthmouth en histoire de l'art et en sciences politiques. Le film permet également d'avoir accès aux images fortes qui ont jalonné son parcours, de la lutte pour les droits civils américains aux travailleurs des mines de soufre en Amérique latine.

BOWLING FOR COLUMBINE

Réalisation: Michael MOORE

et Michael DONOVAN

Canada/États-Unis, 2002., 120 min. (version originale anglaise

avec sous-titres français)

Un documentaire couronné par un Oscar lors de la remise de 2003 sur la popularité des armes aux États-Unis et la violence reliée aux armes à feu. 